\title{
PENDIDIKAN MULTIKULTURAL DI PESANTREN
}

\author{
Mahmudah Rasyid \\ Program Studi Pendidikan Agama Islam Islam, FTIK, IAIN Palu \\ I_zabir@yahoo.co.id
}

\begin{abstract}
ABSTRAK
Pembelajaran multikultural pada dasarnya adalah sistem pembelajaran yang dirancang untuk menciptakan masyarakat yang terinformasi dan terpelajar, bukan masyarakat umum yang menghindari faktor sosial dan budaya yang ada. Pesantren sebagai organisasi pendidikan yang memiliki sisi alternatif dalam menyelesaikan siklus pembelajarannya, yang terletak pada kerangka kerja yang dijalankan antara lain mempersepsikan keberagaman (majemuk, menghargai kesetaraan/keseimbangan, menciptakan ketahanan, dan menghargai kualitas kemanusiaan. Model yang diterapkan pesantren dalam pembelajaran multikultural antar siswa variatif. Pemikiran dan pengalaman seorang kyai tentang Islam yang komprehensif, moderat, berpikiran terbuka, dan bersahabat telah membawa pesantren dan dan pengikutnya menjadi Islam yang rahmatan lil'alamin, bukan Islam yang radikal dan tidak terikat terhadap penganut agama yang berbeda dan kebudayaan yang telah ada. kehidupan yang tercipta di sekitar pesantren. Pengajaran multikultural tidak secara eksplisit diberikan sebagai mata pelajaran atau studi kajian secara spesifik, namun melalui berbagai kesempatan dan latihan dalam pesantren.
\end{abstract}

Kata Kunci : Pendidikan, Multikultural, Pesantren

\begin{abstract}
Multicultural learning in life is a learning system designed to create an informed and educated society, not the general public who avoids existing social and cultural factors. Pesantren as an educational organization that has an alternative side in completing the learning cycle, which lies in the framework that is implemented, among others, perceives diversity (pluralism, appreciates equality / balance, creates resilience, and respects the quality of humanity. The model applied by pesantren in multicultural learning among students is varied. The thoughts and experiences of a kyai about Islam that is complete, moderate, open, and friendly have brought the pesantren and its followers to become a rahmatan lil'alamin Islam, not radical Islam and not related to adherents of different religions and existing cultures. around pesantren Multicultural teaching is not explicitly given as lessons or specific studies, but through various opportunities and exercises in pesantren.
\end{abstract}

Keywords: Education, Multicultural, Pesantren

\section{PENDAHULUAN}

Di Indonesia, pendidikan multikultural, adalah pendidikan yang dapat mencetak siswa yang memiliki kecerdasan yang berkearifan lokal, memiliki rasa toleransi, atau menghasilkan siswa yang memiliki pandangan yang komprehensif, sangat penting untuk dilakukan. Pendidikan multikultural ini akan menyampaikan dan menciptakan individu Indonesia memiliki rasa patriotisme dan pada akhirnya memiliki pilihan untuk menjaga kehormatan negara dari bahaya kemerosotan. Setiap kali diakui oleh sekolah yang dirancang ketat, pendidikan multikultural diterima untuk memberikan pilihan untuk menyampaikan siswa yang moderat dan komprehensif. Menjadikan masyarakat pada umumnya seperti itu penting artinya bagi negara Indonesia yang 
dikenal memiliki penduduk multietnis, multietnis, dan plural.

Pesantren sebagai institusi keagamaan mendapatkan momentum dalam sistem pendidikan nasional setelah keluarnya Undang-Undang No. 20 Tahun 2003 tentang Sistem Pendidikan Nasional. Undang-Undang tersebut menyebutkan bahwa pendidikan keagamaan tidak hanya salah satu jenis pendidikan, tetapi sudah memiliki berbagai bentuknya seperti pendidikan diniyah, pesantren dan bentuk lain yang sejenis.

Ketentuan mengenai pendidikan keagamaan dalam UU Sisdiknas tersebut diatur lebih lanjut dengan peraturan pemerintah No. 55 Tahun 2007 tentang Pendidikan Agama dan pendidikan Keagamaan. Pembelajaran keagamaan berperan mempersiapkan siswa menjadi anggota warga yang menguasai serta mengamalkan nilai ajaran agama dan pakar dibindang ilmu agama. Sebaliknya tujuan pembelajaran keagamaan yaitu terciptanya siswa yang menguasai serta mengamalkan nilai ajaran agamanya serta menjadi pakar ilmu agama yang berwawasan luas, kritis, kreatif, inovatif serta dinamis dalam rangka mencerdaskan kehidupan bangsa yang beriman, bertakwa dan berakhlak mulia.

Sementara itu, pesantren yang benarbenar menjaga kualitas nilai tradisi, memunculkan kesadaran multikultural. Sampai saat ini, wacana lokal dan kebijaksanaan lingkungan pesantren telah diterima sebagai tradisi atau adat istiadat pesantren. Selain itu, gagasan kemajuan pesantren juga dimulai dari tradisi, dengan tujuan agar tidak menemui sejarah yang ada atau tradisi tidak terputus. Pesantren yang dikenal dengan salafiyah atau tardisinal ini, memang berpijak pada tradisi Walisongo yang menunjukkan kualitas ketahanan dalam pembelajaran Islam terutama dalam nilai-nilai toleransi.

Dalam sejarah beridirinya pesantren di Indonesia, ditemui 2 model dalam sejarah pendiriannya. Pada Awalnya, ada yang menuturkan jika pondok pesantren berakar pada tradisi islam, ialah tradisi tarekat.Kedua, pondok pesantren awalnya ialah pengambil alihan dari sistem Pondok
Pesantren yang diadakan orang- orang Hindu serta Budha di Nusantara dengan memakai sistem biara serta serta asrama untuk bhiksu serta pendeta bagaikan tempat pendidikan para pengikutnya.

Sejarah pesantren merupakan sejarah perlawanan kelompok ulama dalam menentang penindasan dan diskriminasi (perbandingan corak kulit, perbandingan perlakuan terhadap sesama masyarakat negeri. Berawal kala rencana pembelajaran modern (Belanda) mulai dirancang secara merata serta diterapkan di hampir seluruh wilayah jajahan dengan memakai konsep stratifikasi social kolonial penduduk jajahan.

Kontribusi pondok pesantren terhadap pembangunan bangsa Indonesia tidaklah terhingga besarnya. Pada zaman penjajahan Belanda dan Jepang, pondok pesantren adalah tempat untuk menggembleng para pejuang, tempat menumbuhkan patriotisme dan nasionalisme. Lahirnya 10 November di Surabaya adalah salah satu bukti, bahwa glora untuk melawan dan mengusir penjajahan.

\section{PEMBAHASAN}

\section{A. Pesantren dan Pendidikan Multikultural}

Islam inklusif merupakan memahami keberagamaan yang berlandaskan pandangan bahwa agama lain di dunia ini bagaikan yang memiliki kebenaran dan bisa membagikan khasiat dan keselamatan untuk penganutnya. Di samping itu, dia tidak sekedar menampilkan pada realitas tentang terdapatnya kemajemukan, melainkan keterlibatan secara aktif terhadap realitas kemajemukan. Kebalikannya, eksklusif merupakan perilaku yang memandang kalau kepercayaan, pemikiran, benak, serta prinsip pada diri sendirilah yang sangat benar, sedangkan kepercayaan, pemikiran, pikiran, dan prinsip yang dianut orang lain merupakan salah, sesat, serta wajib dijauhi. (Anjrah Lelono Broto, 2020)

Di Indonesia, pasca reformasi, tampak gerakan keagamaan yang cenderungradikal seperti momentum yang sangat kuat untuk berkembang. Sebaliknya, jika melihatpraktik keagamaan golongan 
yang sering disebut dengan tradisional Islam, yang berakardi pesantren salafiyah, terkadang dekat dengan sikap inklusif, walaupun tidak semuanya. Bahkan wacana inklusif ini tengah berkembang di kalangan ini, khususnya dalampemikiran kaum mudanya yang mempunyai latar belakang pendidikan pesantren dan akademik. Inklusif karena secara umum kelompok yang paling disebutadalah islam tradisional ini, dengan model pelaksanaan keagamaan yang menajdikan walisongo sebagai contoh. Dan walisongo mengikuti Nabi Muhammad Saw, dan itu dijadikan santri sebagai dasar berkiblat (Mas'ud, 2007).

Penduduk Islam tradisional identik dengan warga NU( Nahdlatul Ulama) yang pasti saja tidak bisa dilepaskan dari pesantren" salafiyah" selaku referensi aplikasi beragama. Perilaku kalangan Islam tradisional yang diwakili NU, pada dasarnya tidak terlepas dari akidah Ahlusunnah waljamaah( Aswaja) yang bisa disebut mengerti moderat (Qomar, 2002).

Pemikiran Aswaja sangat terbuka terhadap pluralisme pemikiran. Berbagai renungan yang mengisi masyarakat Muslim mendapatkan pengakuan yang apresiatif. Untuk situasi ini Aswaja menerima konsekuensi Responsif berbagai cara berpikir, tidak hanya yang benar-benar ada di mata publik (Madzhab Hanafi, Maliki, Syafi'i, dan Hanbali), namunmazahab yang pernah ada, misalnya Imam Daud alZhahiri, Imam Abdurrahman al-Auza'i, Imam Sufyan al-Tsauri, dan lain-lain. (Muhammad, 1999).

Pendidikan multikultural memiliki lima dimensi yang saling berkaitan satu sama lain, yaitu :

1. Content integration, mengoordinasikan berbagai masyarakat dan pertemuan untuk menunjukkan ide-ide penting, spekulasi dan hipotesis dalam mata pelajaran / disiplin ilmu.

2. The Knowledge Construction Process Membawa siswa untuk memahami konsekuensi sosial dari suatu pelajaran

3. An Equity Paedagogy, Mengubah strategi pembelajaran menjadi cara belajar siswa, hal ini dilakukan untuk mendorong prestasi akademik siswa yang berfluktuasi dari ras, budaya dan masyarakat.

4. Prejudice Reduction, Mengenali kualitas ras dan memutuskan strategi belajar untuk siswa.

5. Empowering school culture, Latih siswa untuk mengikuti latihan sekolah dan berkomunikasi dengan semua staf dan siswa dari berbagai bangsa dan ras dengan tujuan akhir untuk membuat budaya akademik. (Banks, 1987).

Pernyataan diatas menyiratkan bahwa Pembelajaran multikultural dapat membawa pengajaran yang dapat membuat masyarakat terinformasi dan terpelajar, bukan masyarakat umum yang menghindari faktor sosial dan sosial yang nyata. Dengan cara ini, meskipun pelatihan multikultural di Indonesia cukup baru untuk dikenal sebagai metodologi yang dipandang lebih masuk akal untuk budaya Indonesia yang heterogen, khususnya pada masa pemerintahan mandiri dan desentralisasi. Dengan demikian, pelatihan multikultural sejalan dengan kemajuan pemerintahan kerakyatan yang dilakukan. Jika hal ini dilakukan "dengan sembrono", itu benarbenar akan menjerumuskan kita ke dalam perpecahan publik. Dengan demikian, pemanfaatan latar belakang sejarah pendidikan di Indonesia menunjukkan bahwa sekolah Islam semua inklusif adalah yayasan pendidikan adat yang paling mapan di Indonesia. Sejak awal perkembangannya, elemen dasar dari life experience school adalah:

1. Mempersiapkan santri untuk memperluas dan menguasai informasi ilmu agama Islam, yang diandalkan untuk menyampaikan kerangka kerja dan menambah peningkatan keilmuan budaya Indonesia.

2. Dakwah menyebarkan Islam.

3. Sebagai pertahanan umat Islam dibidang ahlak

Sesuai dengan kapasitas tersebut, materi yang diajarkan di pondok pesantren semua inklusif adalah materi agama yang diambil dari kitab-kitab klasik tradisional (Depatemen Agama RI, 2004). Seiring dengan perkembangan zaman, peranan pondok pesantren semakin berkembang sebagai landasan yang kokoh, namun juga 
sebagai pusat pengembangan jaringan di berbagai bidang kehidupan. Dengan kerangka yang disebut pesantren, jalan menuju internalisasi agama Islam kepada siswa berjalan sepenuhnya. Dalam pesantren dengan keteladanan dan kepemimpinan seorang sosok kyai serta ustadz dan para pengelola yang khas. Tercipta suatu komunikasi tersendiri yang didalamnya terdapat semua aspek kehidupan, mulai dari pendidikan, ekonomi, budaya, dan organisasi (Depatemen Agama RI, 2004).

Dalam kehidupan pesantren, kyai menerapkan standar kesederhanaan dan kebebasan siswa. Aturan ini menunjukkan agar pelajar dari pesantren dapat menjadi individu yang apresiatif dalam kondisi apapun dan tidak memiliki arti penting dalam kehidupan dunia materialistik. Pelatihan di sekolah Islam inklusif menerapkan standar self government di mana siswa mengelola kehidupan di pesantren yang ditunjukkan dengan batasan pelajaran ketat yang telah diinstruksikan oleh ustasdz, kyai atau pengawas pesantren langsung. Di samping hal itu santri juga diberikan berbakai bekal kemampuan yang nantinya dapat bermanafaat dalam kehidupanya kelak nati, yang berupa sebuah kemampuan untuk berwawasan dalam hal ketrampilan, dan multikulturalisme. Dalam pelaksanaan pendidikan multikultural dapat dibedakan model pembinaan pendidikan multikultural di di pesantren yang dapat dimanfaatkan sebagai daya tarik dalam memajukan pembelajaran multikultural. Model peningkatan pendidikan multikultural adalah sebagai berikut:

1. Kemajuan pendidikan multikultural di pesantren sangat dipengaruhi oleh pemikiran dan pengalaman para tokoh kiai.

2. Pendidikan multikultural di pesantren tidak ditampilkan secara eksplisit melalui mata pelajaran tertentu, namun melalui situasi dan kondisi yang berbeda yang memungkinkan siswa untuk memberikan kualitas multikultural. Islam harus dididik dengan tenang tanpa kebrutalan
3. Metodologi yang digunakan dalam pelatihan Islam kepada siswa adalah metodologi yang komprehensif. Islam diajarkan dalam jiwa rahmatan lil'alamin, bukan Islam yang restriktif dan revolusioner

4. Islam yang diajarkan di pesantren adalah Islam asli yang tidak memusuhi sosial dan adat istiadat di sekitar pesantren

5. Model dakwah yang diterapkan di pesantren salafiyah mengikuti model dakwah Nabi dan Walisongo yang halus dan mengakui budaya lingkungan. Kiai yang berpikir tentang pesantren bukan hanya sebagai inovator di pesantren, tetapi juga sebagai pelopor jaringan di sekitar pesantren.

6. Pelatihan multikultural menjaga kesetaraan, termasuk dalam masalah gender;

7. Pendidikan multikultural menunjukkan perbedaan dan keragaman dan perlawanan. Pesantren menunjukkan kepada siswa berbagai macam perasaan (mazhab) dan mereka harus menghargai perbedaan dan keragaman ini, mengingat perbedaan agama atau keyakinan (Depatemen Agama RI, 2004).

Pondok pesantren merupakan salah satu lembaga pendidikan yang memiliki salah satu sisi yang berbeda dalam melaksanakan proses pendidikannya. Perbedaan tersebut terletak dari sebuah sistem yang di terapkan antara lain:

1. Mengakui keberagaman (plural)

Pesantren dalam proses pendidikannya mengajarkan sebuah perbedaan. Dimana tidak seorangpun di dunia ini yang dapat menolak sebuah kenyataan, bahwa alam semseta ini di ciptakan oleh Allah Swt dalam keadaan beragam (plural), berwarna-warni dan berbeda-beda. Keberagaman ini merupakan sebuah sunatullah yang sudah digarisikan. oleh Allah Swt. Hal menarik dalam hal ini adalah mengapa santri diberikan sebuah pembelajaran tentang keberagaman. Agar para santri mampu berusaha dan pengabdian terbaik kepada Allah di alam semesta ini yang plural. dan memberikan pengajaran mengenai penciptaan alam 
semesta ini dalam keadaan plural ini adalah untuk pengembangan ilmu pemngetahuan dan saling memahami sesama ciptaannya.

Dari hal inilah santri dapat menganalisa dan mencoba berfikir mengenai sebuah realita permasalah atau problem yang ada di pesantren sendiri atau di masyarakat. Yang mana realita yang ada di pesantren itu sendiri beragam permasalah yang dihadapinya. Oleh karena itu pesantren ini menerpkan sebuah pendidikan yang mengajarkan sebauh keberagaman.

2. Menghargai kesetaraan/persamaan

Pesantren selain mengajarkan sebuah proses pendidikan tentang perbedaan atau keberagaman, suku dan ras juga memberikan sebuah pemaparan akan pentingnya sebuah persamaan. Dalam persaaman inilah santri diberikan sebuah gambaran mengenai tugas dari dirinya adalah sama-sama mencari ilmudan mentati sebuah peraturan yang sudah menjadi sebuah kesepakatan bersama. Dan juga mendidikan para santri memiliki sebuh prinsip persatuan dan kesatuan. Karena, manusia di dunia diciptakan didunia samasama menjadi seorang khalifah fil ardhi (pemimpin).

3. Toleransi.

Pesantren merupakan sebuah lembaga pendidikan yang mengajarkan ajaran-ajarn islam kepada santrinya. Yang menjadi titik tekan dari pesantren adalah memberikan kebebasan (toleran) kepada semua santrinya untuk aktif dan kreatif dalam mengekspriskan dirinya dalam berbagai bentuk aktivitas dalam mempelajari sebuah ilmu pengetahuan.

Selain itu pesantren ini juga memberika kebebasan (terbuka) kepada semua golongan, kelompok, komunitas, baik dari muslim maupun non muslim untuk belajar di pesantren ini., walaupun hanya beberapa waktu saja.

\section{Kemanusiaan}

Pesantren juga memberikan kepada semua santri memiliki rasa kemanusian yang tinggi, yang melekat pada diri santri itu sendiri. Santri didik oleh seorang kyai dan ustadznya yang memberikan sebuah pengajaran tentang akan pentingnya sebuah kemanusian. Yang menjadi titik tekan adalah menyiapkan seorang santri yang nantinya menjadi seorang pendamping umat (khadimil umat) kepada semua orang yang ada di masyarakat yang membutuhkan sebuah bantuan bagi orang-orang lemah yang sedang menghadpi berbagai hal permasalah yang dihadapinya (Ainurrofiq, 2003).

Pengembangan pendidikan pesantren yang berwawasan multikulturalisme akan membawa dampak yang positif bagi para santri, diantaranya:

1. Mempertahankan nilai-nilai kebudaya pesantren dengan sebuah prinsip metodologis "memelihara tradisi-tradisi lama yang baik, dan tidak meninggalkan tradisi tradisi baru yang lebih baik".

2. Timbulnya rasa saling menghargai (toleransi) antara santri dengan dengan santri lainnya, santri dengan para masyarakat di sekitar maupun dengan orang yang melakukan kunjungan di pesantren baik sesama santri atau non muslim.

3. Terbiasa untuk hidup bersama, terbiasa untuk mengerjakan hal-hal yang bernilai mulia, seperti menghargai antara sesama santri sendiri (toleransi/tasâmuh), tawasuth (berada di tengah atau moderasi), tawazun (seimbang menjaga keseimbangan), adalah (keadilan), dan terakhir tasyawur (musyawarah).

4. Terbentuknya sikap disiplin para santri dalam kehidupannya. dengan para santri yang lain.

5. Membantu para santri dalam menambah wacana, pengalaman atau ilmu pengetahuan.

6. Menumbuhkan kepekaan santri dalam menganalisa dan cara berfikir dalam kondisi masyarakat (Ainurrofiq, 2003).

Selain itu pengembangan pendidikan pesantrenyang berwawasan multikulturalisme membawa dampak yang positif bagi para santri, diantaranya :

1. Dapat mengetahui dan mempelajari berbagai realita sosial budayayang plural yang ada dimasyarakat. Sehingga santri dapatmenganalisa dan berfikir dengan melihat realita yang ada. 
2. Tumbuhnya rasa saling menghargai dan menghormati antara santridengan non islam.

3. Tumbuhnya suka menolong kepada orang lain. Seperti membantuorang orang lemah yang membutuhkan bantuan (Khadimil ummah).

4. Menumbuhkan sikap saling toleransi antara sesama mahluk ciptaan Allah Swt.

5. Tumbuhnya solidaritas dalam rangka memperkuat rasanasionalisme yang setara (baik antar suku, agama, atau golongan).

6. Menimbulkan rasa nyaman bagi santri dalam menuntut ilmu di pesantren bersama dengan masyarakat (Ma'arif, 2009).

Dengan melihat sistem pendidikan yang diterapkan di pesantren, membawa sebuah dampak angin segar di dunia pendidikan pesantren di indonesia pada saat ini. Dengan menerapkan sebuah konsep pendidikan pesantren berwawasan multikulturalisme, memberikan gambaran mengenai konsep pendidikan yang sudah diajarkan oleh pengasuh dan ustadznya mengandung sebuah konsep nilai-nilai pendidikan multikulturalisme. Yaitu dalam kehidupanya di pesantren para santri menerima pengajaran dengan sebuah kondisi realita kehidupan dipesantren yangsangat mejemuk (plural). adanya persamaan, rasa toleransi (kebebasan), dan rasa kemanusian antara santri, ustadz dan pengasuh pesantren pada umumnya. Dari hal inilah pesantren berani membuka diri dalam mempertahankan tradisi-tradisi pesantren yang ada, dengan menerima sebuah kenyataan yang ada. Yaitu banyaknya agama non muslim yang tertarik untuk mendalami atau hanya mengetahui tentangajaran-ajaran islam di pondok pesantren.

Dari realita inilah pondok pesantren menerapkan nilai-nilai multikulturalisme konsep pengajaran dan pembelajara ilmuilmu agama yang mendalam dan ilmu umum yang berwawasan kebangsaan dan kemasyarakat dalam proses pendidikanya.

\section{B. Pesantren dan Pengembangan Pendidikan Multikultural: (Peran Kyai)}

Peran kyai dalam menciptakan pendidikanmultikultural sangatlah penting. Pesantren sebagai yayasan instruktif adalah sebuah pendirian yang mampu menanamkan kesadaran di antara siswa tentang karakternya sendiri, menggabungkan kepribadian dan membina warga terencana yang hebat dan mendidik dalam budaya yang homogen atau pluralistik (Wiriaatmadja, 2002).

Kemudian kyai berharap dapat mempersiapkan dan mendidik pemikiran santri, memberikan pengajaran yang baik dan tegas, menanamkan keakraban dengan patriotisme dan semangat, menjadi anggota masyarakat yang produktif. Dengan demikian kyai memiliki peranan penting dalam pendidikanmultikultural karena ia merupakan salah satu target dari strategi pendidikan ini.Peran kyai dalam hal ini antara lain:

1. Membangun paradigma keberagamaan Kyai merupakan faktor penting dalam melaksanakan nilai- nilai keberagamaan yang inklusif dan moderat, karena kyai dan pendidik yang memiliki cara pandang pemahaman keberagaman akan memiliki pilihan untuk mendidik dan mengaktualisasikan nilai-nilai keragaman tersebut kepada siswa. Selain kyai, fungsi pesantren juga sangat penting dalam membangun iklim pendidikan yang pluralis dan toleran. Konsekuensinya, pesantren membuat dan mengaktualisasikan hukum lingkungan, khususnya hukum pesantren yang secara eksplisit diterapkan di pesantren tertentu. Dengan berlakunya undang-undang ini dipercaya bahwa Kyai menjadi faktor penting dalam melaksanakan kualitas ketat komprehensif dan moderat, dengan alasan kyai dan instruktur yang memiliki pemahaman dunia ketat moderat akan memiliki pilihan untuk mendidik dan mengaktualisasikan nilai-nilai ragam tersebut. Untuk pelajar. Selain kyai, fungsi pesntren juga sangat penting dalam membangun iklim pendidikan yang pluralis dan toleran. Konsekuensinya, pesantren membuat dan mengaktualisasikan hukum lingkungan, khususnya hukum pesantren 
yang secara eksplisit diterapkan di pesantren tertentu. Dengan berlakunya undang-undang ini, dipercaya bahwa semua komponen saat ini dapat mengetahui bagaimana secara konsisten menghargai orang lain yang berbeda dalam keadaan mereka saat ini.Semua komponen saat ini dapat mengetahui bagaimana secara konsisten menghargai orang lain yang berbeda dalam keadaan mereka saat ini. (Dhofier, 1994).

Dan untuk membangun rasa saling pengertian antar santri, pesantren berperan aktif dalam menggalakkan dialog keberagaman dengan bimbingan kyai dengan tetap pada literatur yang dapat membangun wacana santri tentangpemahaman keragaman dan keberagamaan yang moderat.

\section{Menghargai keragaman bahasa}

Seorang kyai harus memiliki mentalitas tentang "ragam bahasa" dan melatih kualitas-kualitas tersebut di pesantren, untuk menumbuhkan watak siswa sehingga mereka umumnya memandang orang lain yang memiliki beragam dialek, aksen dan dialek yang berbeda. Pada sebagian besar pesantren kyaimenunjukkan sikap dan tingkah laku yang selalumenghargai perbedaan bahasa yang ada, dengan demikian diharapkanlambat laun para santru juga akan mempelajari dan mempraktekkansikap yang sama (Dhofier, 1994).

3. Membangun sensitivitas gender

Dalam pendidikan multikultural, pendidikan memiliki peran yangsangat strategis untuk membangun kesadaran santri tentangpentingnya menjunjung tinggi hak-hak perempuan dan membangun sikap anti diskriminasi terhadap kaum perempuan. Kyai memiliki peran dalam membangun kesadaran santri terhadapnilainilai kesadaran gender dan sikap anti diskriminasi terhadap kaumperempuan di sekolah dengan memiliki wawasanyang cukup tentang kesetaraan gender, mempraktekkan nilai-nilai keadilan gender secara langsung di pesantren dan memiliki sensitifitas terhadap permasalahan gender di pesantren (Dhofier, 1994).

Sementara itu, pesantren juga memiliki peran yang sangat penting dalammenanamkan nilai-nilai tentang kesetaraan dan keadilan gender dengan cara menerapkan undang-undang pesantren anti diskriminasi gender, berperan aktifuntuk memberikan pelatihan gender terhadap seluruh staff termasuk pendidik dan santri agar penanaman nilai-nilai tentang persamaan hak dan sikap anti diskriminasi gender dapat berjalan dengan efektif serta memupuk dan menggugah kesadaran santri tentang kesetaraan gender dan sikap anti diskriminasi terhadap kaum perempuan dengan mengadakan acara-acara seminar atau kegiatan social lainnyayang berkaitan dengan pengembangan kesetaraan gender.

4. Membangun sikap kepeduliaan sosial Kyai memiliki peran terhadap pengembangan sikap peserta didik untuk peduli dan kritis terhadap segala bentuk ketidakadilan social, ekonomi dan politik yang ada di dalam lingkungan sekitarnya maupun di luar lingkungan sekitar. Para kyai umumnya memiliki wawasan yang cukup tentang berbagai macam fenomena sosial yang ada di lingkungan para santri, terutama yang berkaitan dengan masalah kemiskinan, pengangguran, para santri yang tidak dapat melanjutkan sekolah dan lain-lain. Di pesantren kyai menerapkan sikap tersebut dengan cara bersikap adil kepada seluruh santri tanpa harus mengistimewakan salah satu dari mereka meskipun latar belakang statussocial mereka berbeda (Dhofier, 1994).

Selain itu pesantren sebaiknya membuat dan menerapkan peraturan fenomena ketidakadilan social, ekonomi dan politik yang ada di sekitar mereka sehingga diharapkan dapat membangun sikap santri untuk percaya diri, menghargai orang lain dan bertanggung jawab.

5. Membangun sikap anti diskriminasi etnis

Kyai memiliki fungsi yang signifikan dalam menumbuhkan sensitivitas anti diskriminasi terhadap terhadap etnis yang berbeda di pesantren. Oleh karena itu, pengaturan dan pengetahuan yang memadai menjadi sikap melawan segregasi etnis di antara kyai dengan memberikan model langsung melalui cara pandang dan perilaku 
mereka yang tidak berprasangka buruk atau tidak menindas terhadap santri yang memiliki dasar etnis tertentu. Mirip dengan pesantren dalam membangun tatanan siswa dan kesadaran akan pentingnya menghargai dan memusuhi penindasan berbagai identitas dengan mendirikan tempat investigasi atau bertukar diskusi untuk memulai hubungan yang harmonis antar pertemuan etnis.(Dhofier, 1994).

6. Membangun sikap anti diskriminasi terhadap perbedaan kemampuan

Dalam hal ini, kyai sebagai pendorong utama perhatian para santri harus secara konsisten menjaga jarak strategis dari perspektif yang menindas terhadap perbedaan kemampuan santri di pesantren. Dengan memberikan contoh langsung kepada santri, diyakini santri dapat meniru, menerapkan, dan menghimpun kesadaran untuk tidak melakukan aktivitas yang merugikan terhadap mereka yang memiliki berbagai kapasitas, misalnya mahasiswa yang goyah atau memiliki memori rendah, dan lain-lain, agar dapat saling memahami, menghormati dan menghargai satu sama lain (Dhofier, 1994).

7. Membangun sikap anti diskriminasi umur

Pesantren harus mengaktualisasikan pedoman yang intinya menyatakan bahwa segala jenis diskriminasi terhadap umur tertentu dilarang secara hati-hati di pesantren dan mewajibkan santri untuk secara konsisten saling memahami dan menghargai perbedaan usia di sekitarnya. Selain itu, pesantren sebaiknya tidak memberikan batasan umurtertentu bagi seseorang yang akan masuk dan belajar di pesantren tersebut (Dhofier, 1994).

Demikian juga dengan kyai harus memiliki pemahaman dan wawasan yang cukup tentang pentingnya sikap yang tidak diskriminatif terhadap orang lain yang berbeda umur diharapkan dapat mempermudah pendidik untuk memberikan contoh dan bimbingan bagaimana seharusnya bersikap pada orang lain umurnya berbeda. Misalnya, pendidik harus dapatmemberikan perhatian yang sama terhadap santrinya tanpa harus membedakan anak yang lebih tua dengan yang lebih muda.

\section{Contoh Kasus Penerapan Pendidikan Multikultural di Pesantren}

1. Niswatin Faoziah, Peran dan Tantangan Pengembangan Pendidikan Islam Berwawasan Multikultural di Pesantren Sunan Pandanaran: Jurnal Kajian Islam Interdisipliner, Vol. 1 Nomor 2, Desember 2016.

Berdasarkan hasil penelitian diketahui bahwa; (1) nilai-nilai multikultural tampak tercermin dan telah menjadi prinsip di pesantren Sunan Pandanaran Yogyakarta. (2) terdapat empat faktor penting yang berperan dalam pengembangan pendidikan Islam berwawasan multikultural yakni; a. tradisi pengajian kitab kuning, b. paham keagamaan pesantren yang inklusif dan toleran, c. kurikulum pesantren d. peran guru dalam pengembangan nilai- nilai multikultural. (3) Kompetensi beberapa guru yang minim akan wawasan multikultur menjadi hambatan utama dalam pengembangan pendidikan Islam berwawasan multikultural di pesantren. Selain itu, dalam konteks pengembangan pendidikan Islam multikultural, minimnya ruang untuk melakukan refleksi dan kurangnya kesempatan dialog dalam pengajaran kitab kuning menjadi persoalan tersendiri (Faoziah,, 2016).

2. Taufik Qurohman, NIM. 102331162 (2017) Implementasi Pendidikan Multukulturalisme Di Pesantren Mahasiswa An Najah Purwokerto. Skripsi IAIN Purwokerto.

Hasil penelitian: Pendidikan multikulturalisme adalah suatu proses untuk menciptakan lingkungan pendidikan yang setara terhadap seluruh peserta didik, pendekatan dalam pengajaran dan pembelajaran yang didasarkan pada nilainilai demokratis dan menegaskan pluralisme kultur dalam masyarakat yang beragam kultur. Tujuan Berdirinya Pesantren Mahasiswa An Najah yaitu menerapkan pendidikan multikulturalisme serta senantiasa membudayakan sikap inklusif dengan menjalin kerukunan dan toleran dengan pemeluk agama nonmuslim. Segala hal yang dilakukan guna menjaga eksistensi tersebut merupakan sebuah hal yang patut untuk diapresiasi, 
terutama mengenai cara mereka menjaga kekompakan dan kerukunan guna tetap menjalankan kegiatan dan menjaga tali silaturahmi antar santri dan masyarakat serta penganut ajaran lain walaupun berbeda ajaran dan keyakinan.

3. Abdullah Sappe Ampin Maja, Pemahaman Nilai Pendidikan Multikultural Dalam Upaya Membangun Keberagamaan Inklusif Santri Pada Pesantren Modern Datok Sulaiman, Jurnal Voice of Midwifery, Vol. 07 No. 09 September 2017

Penelitian ini membahas tentang bagaimana pemahaman tentang Pendidikan Multikultural di Pesantren Modern Datok Sulaiman Palopo. Permasalahn utama dalam tesis ini adalah, bagaimana pemahaman guru/Pembina dan santri tentang pendidikan Multikultural serta bagaimana upaya yang dilakukan oleh Pembina/guru dalam rangka membangun keberagaan inklusif di lingungan sekolah melalui proses belajar mengajar baik formal maupun non formal .Dalam penelitian ini, penulis menggunakan pendekatan deskriptif kualitatif yakni kajian Library Research dan Field Research. Subjek dalam penelitian ini adalah, pengasuh,Pembina,guru dan santri. Teknik pengumpulan data yang digunakan adalah, observasi, wawancara,dan dokumentasi. Pemeriksaan keabsahan data menggunakan teknik cross check. Sedangkan untuk analisis data digunakan teknik analisis deskriptif.

Hasil penelitian menunjukkan beberapa kesimpulan penting, dalam bidang pendidikan. Sebenarnya pesantren modern Datok Sulaiman sulit untuk mengatakan bahwa lembaga pendidikan tersebut adalah modern sesuai dengan nama yang melekat dalam lembaga tersebut, yang ada adalah model campuran antara corak tradisional dan modern. Kalangan pesantren Datok Sulaiman tampaknya telah mengambil dasar al-muhafadhotu 'ala qadimi al-salih wa al-akhdu bi jadidi al-aslah (mempertahankan yang lama yang masih baik dan mengambil yang baru demi kebaikan) sebagai pijakan. Oleh karena itu model pembelajaran dengan system bandongan dan sorogan sebagai ciri tradisional dapat berjalan secara bersamaan dengan system klsikal dengan penyediaan kurikulum yang terarah sebagai ciri modern. Demikian pula dalam hal pemikiran, pada kenyataannya Pembina dan guru dalam proses pelaksanaan belajar mengajar baik formal maupun non formal telah memahami dan mempraktekkan nilai-nilai multikultural dalam lingkungan pesantren (Maja, 2017).

\section{KESIMPULAN}

Model yang diterapkan oleh pesantren dalam pendidikan multikultural dikalangan para santri bervariasi. Ide-ide dan wawasankiai mengenai Islam yang inklusif, moderat, toleran, dan harmoni membawa pesantrendan para santrinya memperoleh Islam yang ramah dan rahmatan lil'alamin, bukan Islamyang radikal dan kaku terhadap penganut agama lain dan juga terhadap budaya-budayayang berkembang di sekitar pesantren. Pendidikan multikultural tidak secara khususdiberikan dalam bentuk mata pelajaran atau kajian khusus, tetapi melalui berbagai kesempatan dan aktivitas di pesan.

Pendidikan pesantren memiliki kontribusi yang penting dalam pengembangan nilai-nilai multikultural seperti pemahaman inklusif dan moderat, tradisi pengajian kitabkitab kuning, kurikulum pesantren dan peran serta guru pendidikan agama di pesantren maupun di madrasah Aliyah. Adapun hambatan yang dihadapi oleh pesantren Sunan Pandanaran adalah tidak meratanya kemampuan dan wawasan guru terkait nilainilai multikultural dalam pendidikan. Peristiwa-peristiwa yang cenderung intoleran terhadap perbedaan masih ditemui meskipun dalam skala yang tidak cukup masif. Dengan demikian, perlu upaya dialog dan sosialisasi terkait dengan multikulturalisme yang komperhensif dengan mengakomodasi tradisi-tradisi yang selama ini mengakar kuat di pesantren

Upaya-upaya yang dilakukan guru dan Pembina pesantren adalah menampilkan Islam sebagai ajaran yang menjunjung tinggi sikap ramah tamah, tidak kaku, bersikap moderat, dan 
merespon adanya perbedaan serta syarat dengan nilai-nilai multicultural dari segi pemikiran dan praktek keagamaan pesantren tersebut tidak kaku, tidak tekstual. Prinsip mendasar dalam pesantren tersebut syarat dengan nuansa pemahaman nilai-nilai multicultural, dikarenakan mereka memegang idiologi Ahlu Sunnah Waljamaah. Yang pada kenyataannya idiologi tersebut dapat mengikuti arus modernisasi dan globalisasi, baik dalam hal pemikiran Islam, praktek pendidikan, maupun interaksi dengan semua golongan dikarenakan landasan yang dipakai kalangan pesantren adalah inklusif, terbuka dan mampu mengambil hal-hal yang baru untuk kebaikan.

\section{DAFTAR PUSTAKA}

Ainurrofiq, Dawan. (2003). Emoh Sekolah, Menolak Komersialisasi Pendidikan dan Kanibalisme Intelektual, Menuju Pendidikan Multikultural. Jakarta: Inspeal Ahimsakarya Press.

Banks, James A. (1987). Teaching Strategis for Ethnic Studies. Boston: Allyn and Bacon Inc 9.

Depatemen Agama RI. (2004). Profil Pondok Pesantren Mu'adalah. Jakarta: Departemen Agama R.I.

Dhofier, Zamakhsyari. (1994). Tradisi Pesantren: Studi Tentang Pandangan Hidup Kyai. Jakarta: LP3ES.

Faoziah, Niswatin. (2016). Peran dan Tantangan Pengembangan Pendidikan Islam Berwawasan Multikultural di Pesantren Sunan Pandanaran. Jurnal Kajian Islam Interdisipliner, 1(2).

Husein, Muhammad. (1999). Memahami Sejarah Ahlus Sunnah Waljamaah: Yang Toleran Dan Anti Ekstrem”. dalam Imam Baehaqi (ed.). Kontroversi as waja. Yogyakarta: LkiS.
Lelono Broto, Anjrah. "Pluralisme dan Multikultural" http://maulanusantara. wordpress.com/2010/01/09/pluralism e-dan-multikultural/, Diakses 9 April 2020 .

Ma'arif, Ahmad Syafi'i. Islam Dalam Bingkai Keindonesiaan dan Kemanusiaan: Sebuah Refleksi Sejarah. Bandung: Mizan, 2009.

Mas'ud, Abdurrahman. (2007). Memahami Agama Damai Dunia Pesantren. Jakarta: LP3ES.

Qomar, Mujamil. (2002). NU Liberal; Dari Tradisionalisme Ahlusunnah $\mathrm{Ke}$ Universalisme Islam. Bandung: Mizan.

Qurohman, Taufik. (2017). Implementasi Pendidikan Multukulturalisme di Pesantren Mahasiswa An Najah Purwokerto. Skripsi, IAIN Purwokerto.

Sappe Ampin Maja, Abdullah. (2017). Pemahaman Nilai Pendidikan Multikultural Dalam Upaya Membangun Keberagamaan Inklusif Santri Pada Pesantren Modern Datok Sulaiman, Jurnal Voice of Midwifery, 07(09). 